\title{
A REPORT ON TWO SPECIES OF TOMATO RESISTANT TO THE TOMATO DISEASE KNOWN AS "TISIS" IN PUERTO RICO
}

In a previous note ${ }^{1}$ the author reported the presence in Puerto Rico of a virus disease of tomatoes known locally as "tisis". The disease markedly affects the development and fruit production of the plant and, although its incidence has been very low up to now, it might constitute a serious menace to tomato-growing in the Island if it ever attained epidemic proportions. The disease is transmitted only by grafting and, symptomatologically, it closely resembles the Brazilian curly top of tomatoes as described by Bennett and Costa.

The curly top virus (Ruga verrucosans Carsner and Bennett) causes very severe losses of tomatoes in some sections of the United States. Other strains of the virus occur in some parts of South America. Unfortunately no marked resistance has yet been incorporated in a variety of good commercial quality.

Doolittle ${ }^{2}$ has recently reviewed the literature concerning the use of resistant varieties and species of tomato in the production of crosses with high resistance to curly top. He cited the varieties Red Peach and Ojo de Venado,

1 Adsuar, J., A disease of tomato in Puerto Rico resembling the Brazilian top of tomatoes, J. Agr. Univ. P. R. 39 (2) 113-4, 1955.

2 Doolittle, S. P., The use of wild Lycopersicon species for tomato disease control, Phylopath. 44 (8) 409-15, 1954. 
both lacking a very high level of resistance, and the species $L$. peruvianum var. humifusum, $L$. peruvianum var. dentatum, and $L$. chilense as possessing a high resistance to curly top.

In view of the similarity already noticed between our tomato "tisis" disease and the strains of curly top affecting tomatoes in South America we decided to test some of the curly top-resistant species of tomatoes reported in the literature against our tomato virus.

Seeds of Lycopersicum peruvianum var. dentatum and $L$. glandulosum, two species reported as resistant to curly top, were kindly supplied by M. M. Hoover of the USDA Regional Plant Introduction Station, Ames, Iowa. Also included in the tests, although not mentioned in the literature as resistant, were the species $L$. hirsutum and $L$. glabratum obtained through the courtesy of A. Sawant of the Plant Breeding Department of this Station.

All the species tested, with the exception of $L$. hirsutum and $L$. glabratum that were obtained from rooted cuttings, were grown from seed in the greenhouse in 6 -inch pots. The plants were side-grafted when about $11 / 2$ feet tall with scions taken from $L$. esculentum var. Marglobe tomatoes showing symptoms of "tisis". Reciprocal grafts were also made using diseased Marglobe plants as stock. The plants were kept in the greenhouse for at least 1 month after grafting.

Both $L$. hirsutum and $L$. glabratum proved fully susceptible to the virus. No trouble was experienced in grafting those two species on infected Marglobe tomatoes. On the other hand, the majority of the grafts performed with $L$. peruvianum var. dentatum and $L$. glandulosum did not take. However, no symptoms of the disease developed in those scions that were grafted and then grew successfully. It is concluded that both $L$. peruvianum var. dentatum and $L$. glandulosum apparently are not affected by the virus causing the "tisis" of tomatoes in Puerto Rico. 